\title{
Protein Synthesis and Degradation During Regression of Thyroxine- induced Cardiac Hypertrophy
}

\author{
Patrick S. Coleman', Michael S. Parmacek², Michael Lesch' and Allen M. Samarel ${ }^{3}$ \\ Sections of Cardiology, Departments of Medicine, ${ }^{1}$ Northwestern University Medical School, Chicago, \\ IL 60611, USA, ${ }^{2}$ University of Michigan School of Medicine, Ann Arbor, MI 48109, USA, \\ ${ }^{3}$ Loyola University Stritch School of Medicine, Maywood, IL 60153, USA
}

(Received 14 November 1988, accepted in revised form 24 April 1989)

\begin{abstract}
P. S. Coleman, M. S. Parmacek, M. Lesch and A. M. Samarel. Protein Synthesis and Degradation During Regression of Thyroxine-induced Cardiac Hypertrophy. Journal of Molecular and Cellular Cardiol (1989) 21, 911 -925. To characterize changes in rates of protein turnover during regression of thyroxine-induced left ventricular hypertrophy, New Zealand White rabbits received intravenous thyroxine $(200 \mu \mathrm{g} / \mathrm{kg} / \mathrm{d})$ for 9 days. Thyroxine was withheld, and in vivo protein turnover was evaluated on the 10th, 15th and 20th days. Animals not receiving thyroxine served as controls. Heart rate, blood pressure, and rate-pressure product were measured to correlate changes in cardiac work with protein turnover rates during the development and regression of hypertrophy. Thyroxine administration produced left ventricular hypertrophy by increasing the rate of protein synthesis (from $37.9 \pm 8.9$ to $61.1 \pm 15.3 \mathrm{mg} / \mathrm{day} ; P<0.05$ ) to a greater degree than protein degradation (from $29.8 \pm 8.9$ to $48.2 \pm 15.3 \mathrm{mg} /$ day for control and thyroxine-treated animals, respectively; $P<0.05)$. Cessation of thyroxine administration resulted in an eventual return of left ventricular mass to that of normally growing control animals. The major observation noted during thyroxine withdrawal was a return of protein synthetic rates to normal. Absolute rates of protein degradation remained elevated, whereas fractional protein degradative rates (i.e. the fraction of total protein degraded per day) were unchanged by the administration and withdrawal of thyroxine. These results indicate that suppression of both physiological and hormone-induced growth following cessation of thyroxine resulted from a decrease in cardiac protein synthetic rates and an increased rate of flux through the protein degradative pathway(s), while fractional rates of protein degradation (and thus average protein half-life) remained unchanged. The development and regression of thyroxine-induced hypertrophy correlated with thyroxine-mediated alterations in cardiac work.
\end{abstract}

Key Words: Thyroxine; Thyrotoxicosis; Heart Enlargement; Muscle Proteins; Kinetics; Cardiac Work; Proteolysis; Myofibril.

\section{Introduction}

Hypertrophy is an adaptive response of ventricular myocardium to a variety of physiological and pathological stimuli. Removal of the stimulus responsible for the growth process usually results in a return of cardiac mass to normal. For example, regression of cardiac hypertrophy following reversal of chronic left ventricular pressure overload has been demonstrated in both experimental animals and man (Beznak et al., 1969; Pandis et al., 1984).
Experimental models of chronic volume overload have been less extensively studied, but replacement of the aortic valve in humans with aortic insufficiency has often, but not always, been associated with a return of ventricular mass towards normal (Pandis et al., 1984). The intracellular mechanisms responsible for the regression of myocardial hypertrophy are poorly understood, but must ultimately depend upon changes in the opposing processes of cardiac protein synthesis and de-

Abbreviations: TGP-total cardiac protein; DNA-deoxyribonucleic acid; RNA-ribonucleic acid; LV-left ventricle; $\mathrm{RV}$ - right ventricle; $\mathrm{R}_{\mathrm{s}}$-absolute rate of protein synthesis; $R_{\mathrm{g}}$-absolute rate of protein accumulation; $\mathrm{R}_{\mathrm{d}}$-absolute rate of protein degradation; $\mathrm{K}_{\mathrm{s}}-$ fractional rate of protein synthesis; $\mathrm{K}_{\mathrm{g}}$-fractional rate of protein accumulation; $\mathrm{K}_{\mathrm{d}}-$ fractional rate of protein degradation.

All correspondences should be sent to: Allen M. Samarel, Department of Medicine, Loyola University Medical Center, 21605 First Ave, Maywood, IL 60153, USA. 
gradation. Alterations in the rates of one or both of these processes must explain the cessation of the growth process and the regression of myocardial protein mass.

Thyroxine administration is a reproducible and extensively studied model for the development of cardiac hypertrophy. We have previously shown that thyroxine-induced cardiac hypertrophy is associated with both increased fractional and absolute rates of in vivo protein synthesis, as well as increases in the efficiency and capacity for protein synthesis (Parmacek et al., 1986). Measurements of protein degradative rates in this hormone induced model of hypertrophy vary, but in all cases, hypertrophy occurs because the accelerated rate of new protein synthesis exceeds the rate of degradation (Morgan et al., 1987).

Regression of thyroxine-induced cardiac hypertrophy has been less extensively studied. In isolated, perfused rat hearts studied 4 days after the cessation of thyroxine administration, Sanford et al. (1978) demonstrated regression of myocardial mass that was associated with a decrease in both the fractional rates of cardiac protein synthesis and degradation. However, due to methodological difficulties in assessing in vitro rates of protein degradation, direct comparisons of the rates of protein synthesis and degradation during regression could not be made. Therefore, these in vitro studies did not define to what extent each process contributes to the regression of cardiac hypertrophy in vivo following the cessation of thyroxine administration.

The proximal stimulus responsible for accelerated protein synthesis in excess of degradation during thyroxine administration remains unclear. Thyroxine interacts with nuclear receptors to induce the synthesis of a variety of new cardiac proteins, including $\alpha$ myosin heavy chain (Zak et al., 1982; Klein, 1988; Everett et al., 1984; Gustafson et al., 1986). In addition, thyroxine treatment alters peripheral hemodynamics, thus changing the loading conditions of the left ventricle. Recent evidence has emphasized the importance of cardiac work necessary for the development of hypertrophy during thyroxine administration (Klein et al., 1986; Korecky et al., 1987). In addition, cessation of thyroxine administration may not result in the immediate resolution of the thyroxine-induced changes in ventricular loading. Thus, analysis of regression from thyroxine-induced cardiac hypertrophy requires that hemodynamic changes occurring after cessation of hormone administration be correlated with changes in ventricular mass and ultimately, changes in the rates of cardiac protein synthesis and degradation.

The objectives of this study were to assess the in vivo rates of protein synthesis and degradation in juvenile rabbits following administration and cessation of thyroxine. Noninvasive hemodynamic parameters were measured in order to correlate measurements of ventricular mass and rates of protein turnover with indices of cardiac work. Data are presented which indicate that suppression of both physiological and hormone-induced growth following cessation of thyroxine results from a decrease in the rate of left ventricular protein synthesis and an increased rate of flux through the protein degradative pathway(s). However, fractional rates of protein degradation (and thus average protein half-life) remain unchanged during regression. Furthermore, observed changes in the rates of protein synthesis temporally correlate with the resolution of increased cardiac work which occurs following withdrawal of thyroxine.

\section{Methods}

\section{Reagents}

L- $\left[2,3,4,5-{ }^{3} \mathrm{H}\right]$ leucine $(110 \mathrm{Ci} / \mathrm{mmol})$ was obtained from ICN Biomedics, Costa Mesa, CA, USA [N-methyl ${ }^{14} \mathrm{C}$ ]dansyl chloride (112 $\mathrm{mCi} / \mathrm{mmol}$ ) was obtained from Research Products International, Rolling Meadows, IL. Lthyroxine (Sigma Chemical Co., St. Louis, MO, USA) was dissolved in $140 \mathrm{~mm} \mathrm{NaOH}$ to achieve a final concentration of $4 \mathrm{mg} / \mathrm{ml}$ at $\mathrm{pH}$ 10.5. All other reagents were of the highest grade commercially available, and were obtained from Baxter S/P, McGaw Park, IL, and the Sigma Chemical Co., St Louis, MO, USA.

\section{Experimental animals}

Male New Zealand white rabbits (Lesser's Rabbitry, Union Grove, WI) were used in all experiments. Animals were acclimated to the 
Northwestern University animal facility for 1-3 weeks and weight gain documented prior to randomization to control or thyroxinetreated groups. Body weights and physiological measurements were obtained daily during the acclimation period to establish baseline indices for normal, growing rabbits and to familiarize the animals with handling and measurement procedures. Animals weighing 1.90 to $2.10 \mathrm{~kg}$ were randomly assigned to either the control $(\mathrm{C}-0)$ or thyroxine-treated groups (Fig. 1). Thyroxine-treated animals received daily intravenous injections of Lthyroxine $(200 \mu \mathrm{g} / \mathrm{kg})$ for 9 days. Ilormone administration was then discontinued, and the animals were randomly assigned to regression groups $(\mathbf{R}-0, \mathbf{R}-1, \mathbf{R}-3, \mathbf{R}-5, \mathbf{R}-7$ and $\mathbf{R}-10)$. The $R-0$ group consisted of rabbits that had not received thyroxine for $24 \mathrm{~h}$, and were considered to have undergone no regression from thyroxine-induced cardiac hypertrophy. In the remaining thyroxine-treated animals, cardiac hypertrophy was subsequently allowed to regress for $1,3,5,7$ and 10 days, respectively. Each group consisted of a minimum of four animals. Rabbits were housed and fed ad libitum, as previously described (Samarel et al., 1981).

\section{Physiological measurements}

Physiological parameters and animal weight were measured daily between 7:00 and 10:00 am. Body temperature was obtained using a flexible rectal probe attached to a digital thermometer. Respiratory rate was obtained over a 15 s period. Heart rate was obtained using a $6 \mathrm{~s}$ rhythm strip generated from a 3lead electrocardiogram. Systolic and diastolic blood pressures were obtained using a GrantRothschild capsule (Wilson et al., 1975) placed over the right central ear artery. The mean of 3 determinations was recorded. Pulse pressure was calculated as the difference between systolic and diastolic blood pressures. Ratepressure product was calculated as the product of systolic blood pressure and heart rate. Daily intravenous injections of thyroxine were

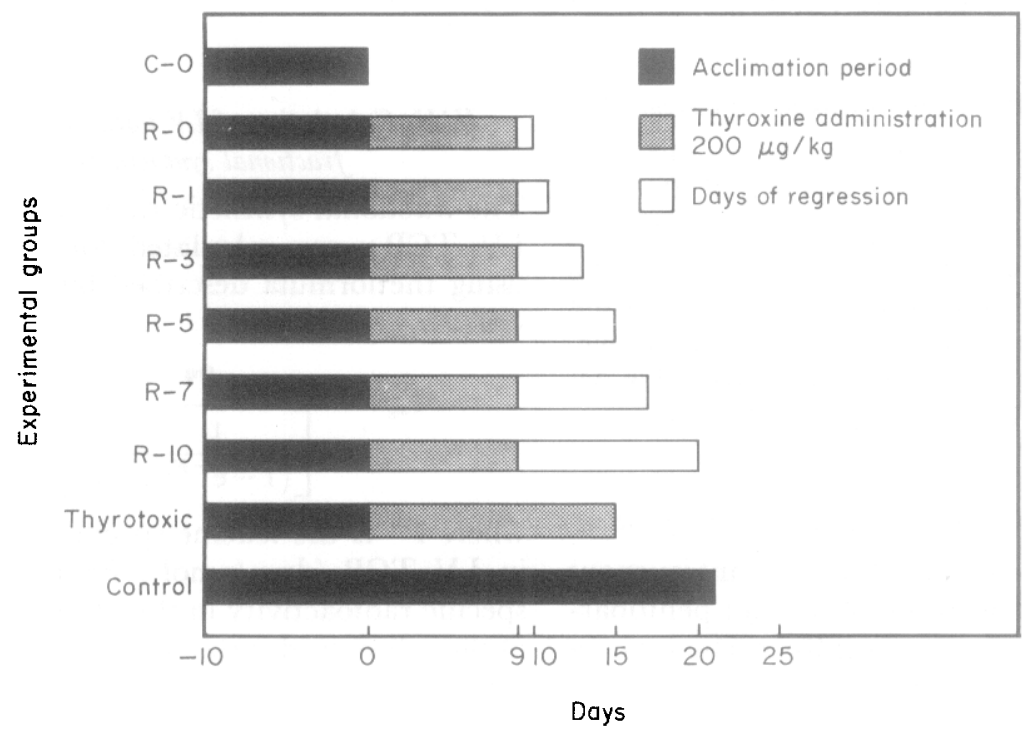

FIGURE 1. Experimental protocol used to assess regression of thyroxine induced cardiac hypertrophy. All animals were acclimated prior to inclusion into this study. Animals weighing 1.90 to $2.10 \mathrm{~kg}$ were randomly assigned to either the baseline group of the present study $(\mathrm{C}-0)$ or thyroxine-treated groups. Thyroxine-treated animals received daily intravenous injections of $\mathrm{L}$-thyroxine $(200 \mu \mathrm{g} / \mathrm{kg})$ for 9 days. Hormone administration was then discontinued, and the animals were randomly assigned to regression groups $(R-0, R-1, R-3, R-5, R-7$ and $R-10)$. The $R-0$ group consisted of rabbits that had not received thyroxine for $24 \mathrm{~h}$, and were considered to have undergone no regression from thyroxine-induced cardiac hypertrophy. In the remaining thyroxine-treated animals, cardiac hypertrophy was subsequently allowed to regress for $1,3,5,7$ and 10 days, respectively. Each group consisted of a minimum of four animals. Control and thyrotoxic animals are included to demonstrate the treatment of animals used to generate the growth curves in Figure 3. (From Parmacek et al., 1986) 
administered after all physiological measurements had been completed.

\section{IV. $\left[{ }^{3} H\right]$ Leucine infusion technique}

Left ventricular (LV) total cardiac protein (TCP) synthesis was measured in vivo in $\mathrm{C}-0$, $\mathrm{R}-0, \mathrm{R}-5$ and $\mathrm{R}-10$ animals $(8$ rabbits from each group) by the $\left[{ }^{3} \mathrm{H}\right]$ leucine constant infusion method (Parmacek et al., 1986). All infusions were begun between 8:00 and 9:00 a.m. to control for diurnal variation in TCP synthetic rates. Lightly restrained rabbits received an intravenous injection of sodium heparin $(1000 \mu / \mathrm{kg})$ followed by a continuous intravenous infusion of $\mathrm{L}-[2,3,4,5$ $\left[{ }^{3} \mathrm{H}\right]$ leucine, $150 \mathrm{~mm} \mathrm{NaCl}, 10 \mu / \mathrm{ml}$ heparin, $100 \mu \mathrm{M}$ unlabeled leucine (final leucine specific radioactivity $=3750 \mu \mathrm{Ci} / \mu \mathrm{mol}$ ) at a rate of $1.33 \mathrm{ml} / \mathrm{h}(500 \mu \mathrm{Ci} / \mathrm{h})$ for $4 \mathrm{~h}$ into a catheterized marginal ear vein. Arterial blood samples $(0.6-1.0 \mathrm{ml})$ were obtained from the contralateral ear at $0,5,10,20,30,60,120$, 180 and $240 \mathrm{~min}$ during the infusion. The volume of sampled blood was replaced with an equal volume of sterile isotonic saline.

\section{Plasma total and free thyroxine measurements}

Total and free thyroxine concentrations were measured in the plasma of $\mathrm{C}-0, \mathrm{R}-0, \mathrm{R}-5$, $\mathrm{R}-10$ animals used for protein synthetic experiments. Prior to infusion of $\left[{ }^{3} \mathrm{H}\right]$ leucine, blood samples were obtained and the plasma was assayed using a commercially available, direct antibody RIA method (Amerlex-M, Amersham, Arlington Heights, IL, USA).

\section{Determination of ventricular tissue composition}

All animals were killed by an intravenous injection of an overdose of sodium pentobarbital. The heart was rapidly excised via a median sternotomy incision and placed into $150 \mathrm{~mm} \mathrm{NaCl}\left(4^{\circ} \mathrm{C}\right)$ to remove blood. The heart was blotted dry, trimmed of fat and major blood vessels, and weighed. After determination of total heart weight, the atria and right ventricular free wall were excised. The $L V$, consisting of the left ventricular free wall and septum, and the right ventricle (RV), were weighed separately, frozen in liquid nitrogen and stored at $-80^{\circ} \mathrm{C}$.

Approximately $1 \mathrm{~g}$ of $\mathrm{LV}$ tissue from each heart was finely minced and suspended in 19 vol of $100 \mathrm{~mm} \mathrm{KCl}, 250 \mu \mathrm{M}$ potassium thioglycolate, pH 6.8. The tissue was homogenized by four $15 \mathrm{~s}$ bursts in a Polytron PCU homogenizer (Brinkman Instruments, Westbury, NY, USA). A portion of the LV tissue homogenate was used for protein determination by the method of Lowry et al. (1951). Additional portions were removed for RNA and DNA determination. Total RNA concentration was analyzed by the method of Munro and Fleck (1966). DNA concentration was assessed using a minor modification of the method of Cesarone et al. (1979). Results were expressed both as mg of total RNA or DNA per gram LV wet weight, and as $\mathrm{mg}$ of total protein or RNA per mg of total DNA.

\section{Determination of leucine specific radioactivity in plasma and $L V$ total protein fractions}

Leucine specific radioactivity in the plasma and in TCA-precipitable total cardiac protein (TCP) was determined as previously described (Parmacek et al., 1986).

\section{Calculation of LV total cardiac protein fractional synthetic rates}

The fractional synthetic rates $\left(K_{\mathrm{s}}, \% /\right.$ day $)$ of LV TCP were calculated for each animal using the formula described by Everett et al. (1979):

$$
\mathrm{K}_{\mathrm{s}}=\frac{P^{*}}{F^{*}\left[\frac{\mathrm{t}}{\left(1-\mathrm{e}^{-\mathrm{K}_{\mathrm{f}} \mathrm{t}}\right)}-\frac{1}{K_{\mathrm{f}}}\right]} \times 100
$$

where $P^{*}$ is the leucine specific radioactivity in LV TCP (dpm/nmol), $F^{*}$ is the leucine specific radioactivity in the plasma at the end of the infusion (dpm/nmol), and $K_{\mathrm{f}}$ is the first order rate constant $\left(\right.$ days $^{-1}$ ) describing the rate of rise of plasma leucine specific radioactivity to plateau $\left(F_{\max }^{*}\right.$ values were determined for each infusion experiment by non-linear, non-weighted regression analysis, as previously described (Parmacek et al., 1986). This method assumes that the specific radioactivity of leucyl-tRNA (the immediate precursor for protein synthesis) rapidly and completely equilibrates with the plasma leucine specific radioactivity in all experimental groups. 


\section{Calculation of plasma leucine flux}

Plasma leucine flux, an estimate of whole body protein synthesis (Waterlow and Stephen, 1967; Garlick et al., 1975), was calculated for each infusion animal using the following formula:

leucine flux $(\mu \mathrm{mol} / \mathrm{h})=$

infusion rate $(\mu \mathrm{Ci} / \mathrm{h}) F_{\max }^{*}(\mu \mathrm{Ci} / \mu \mathrm{mol}) / 100 \mathrm{~g}$ body weight

\section{$X$. Determination of $L V$ total cardiac protein accumulation rates}

Values of LV TCP accumulation rates $\left(R_{\mathrm{g}}\right)$ for control and thyrotoxic rabbits had been published in our previous studies of thyroxineinduced left ventricular hypertrophy (Parmacek et al., 1986; Samarel et al., 1987). LV TCP accumulation rates $\left(R_{\mathrm{g}}\right)$ in the regression animals of the present study were directly determined from measurements of LV TCP and heart weight. Mean LV TCP content was plotted vs. days of regression. Sequential fitting of the data to first, second and third degree polynomial equations was then performed and the improvement in fit was assessed by the significance of the partial F-value for the parameter of highest degree. TCP $R_{\mathrm{g}}$ was then calculated as the first derivative of the best fitting function describing LV TCP content vs. time and expressed as $\mathrm{mg}$ protein accumulated/day.

Instantaneous fractional accumulation rates $\left(K_{\mathrm{g}}, \% /\right.$ day $)$ were obtained by dividing the TCP $R_{\mathrm{g}}$ by the LV TGP content/100.

\section{$X I$. Determination of LV protein turnover in control, thyrotoxic, and regression animals}

LV TCP synthetic rates $\left(\boldsymbol{R}_{\mathrm{s}}\right.$, mg protein synthesized/day) were calculated as the product of the fractional synthetic rate $\left\langle\boldsymbol{K}_{\mathrm{s}}\right.$, $\% /$ day) and the corresponding total cardiac protein pool size [ $(\mathrm{mg}$ protein $/ \mathrm{g} \mathrm{LV}$ wet $\mathrm{wt}$ ) $\times(\mathrm{g} \mathrm{LV}$ wet $w \mathrm{t} / 100)]$ of each animal.

LV TCP degradative rates were calculated indirectly as either the fractional rate of degradation or the absolute rate of degradation. The fractional degradative rate $\left(\boldsymbol{K}_{\mathrm{d}}, \% /\right.$ day $)$ was calculated as the difference between fractional synthetic rates $\left(\boldsymbol{K}_{\mathrm{s}}, \% /\right.$ day $)$ and fractional accumulation rates $\left(K_{\mathrm{g}}, \% /\right.$ day $)$ for each animal. $K_{\mathrm{d}}$ estimated the fraction of the
TCP pool degraded per day. The absolute rate of LV TCP degradation $\left(R_{\mathrm{d}}\right.$, mg protein degraded/day) was calculated as the difference getween LV TGP synthetic rates $\left(R_{\mathrm{s}}\right), \mathrm{mg}$ protein/day) and LV TCP accumulation rates $\left(R_{\mathrm{g}}\right.$, mg protein/day). TCP $R_{\mathrm{d}}$ estimated the flux through the protein degradative pathway(s), and was affected by alterations in both the TCP pool size and/or the fractional amount of the pool degraded per day $\left(K_{\mathbf{d}}\right)$.

The efficiency of cardiac protein synthesis was assessed in each animal used in leucirie infusion experiments. Efficiency was calculated as TCP $R_{\mathrm{s}}$ divided by the total RNA content and expressed as $\mathrm{mg}$ protein synthesized/day/mg total RNA (Millward et al., 1973).

\section{Data analysis}

Unless otherwise stated, all results were expressed as mean \pm s.D. Normality was demonstrated with the Wilks-Shapiro test and homogeneity of variance was established with Levene's test. One-way analysis of variance (ANOVA) followed by the Student-NewmanKeuls test were used for statistical comparison between multiple groups. Polynomial curve fitting and statistical analysis was performed using the PROPHET computer system (Division of Research Resources, NIH).

\section{Results}

\section{Cardiac growth during administration and withdrawl of thyroxine}

Sixty-nine rabbits were used to assess myocardial growth and composition after administration and withdrawal of thyroxine (Table 1). Initial body weights for all animals were similar. Administration of thyroxine for 9 days ( $R-0$ animals) resulted in a $20 \%$ decrease in body weight as compared to $\mathrm{C}-0$ animals. $\mathrm{By}$ the fifth day after cessation of hormone administration, the thyroxine-induced weight loss had resolved, and the animals continued to gain weight through the 10th day following hormone withdrawal. Cardiac hypertrophy was evident after 9 days of thyroid hormone, as reflected by a $25 \%$ increase in total heart weight. Proportional increases in RV and LV weights were observed. Total heart weight remained relatively constant following withdrawal of thyroxine. In the $\mathrm{R}-0$ animals, the 


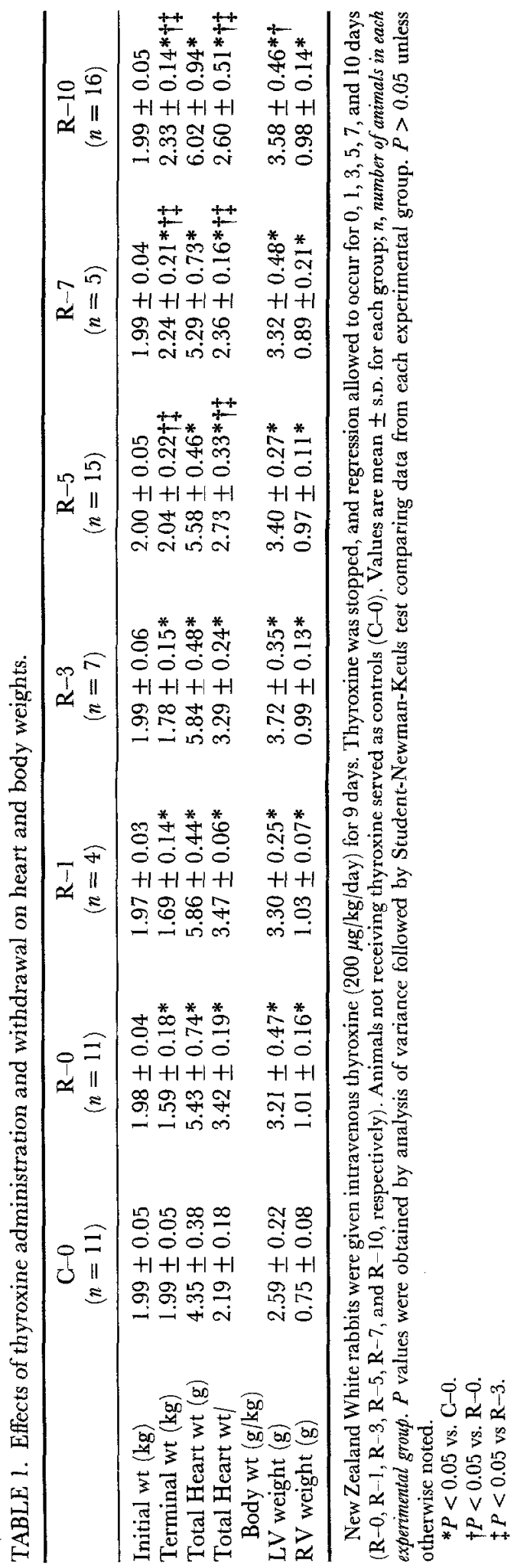


total heart weight to body weight ratio increased $56 \%$ as compared to $\mathrm{C}-0$ rabbits. By the fifth day following discontinuation of thyroxine, the total heart weight to body ratio was significantly less than $R-0$ and $R-3$ values and continued to decrease through day 10 of regression. Given the relative constant values for total heart weight, decreases in total heart weight to body weight ratios seen after cessation of thyroxine administration were largely the result of increases in body weight.

\section{Physiological changes associated with administration and withdrawal of thyroxine}

The results of physiological measurements made during the treatment protocol are depicted in Figure 2. A significant increase in heart rate was observed during the course of thyroxine administration $(260 \pm 22$ vs. $360 \pm 35$ beats/min for $\mathrm{C}-0$ and $\mathrm{R}-0$ animals, respectively; $P<0.05$ ). The mean heart rate remained significantly elevated in R-3
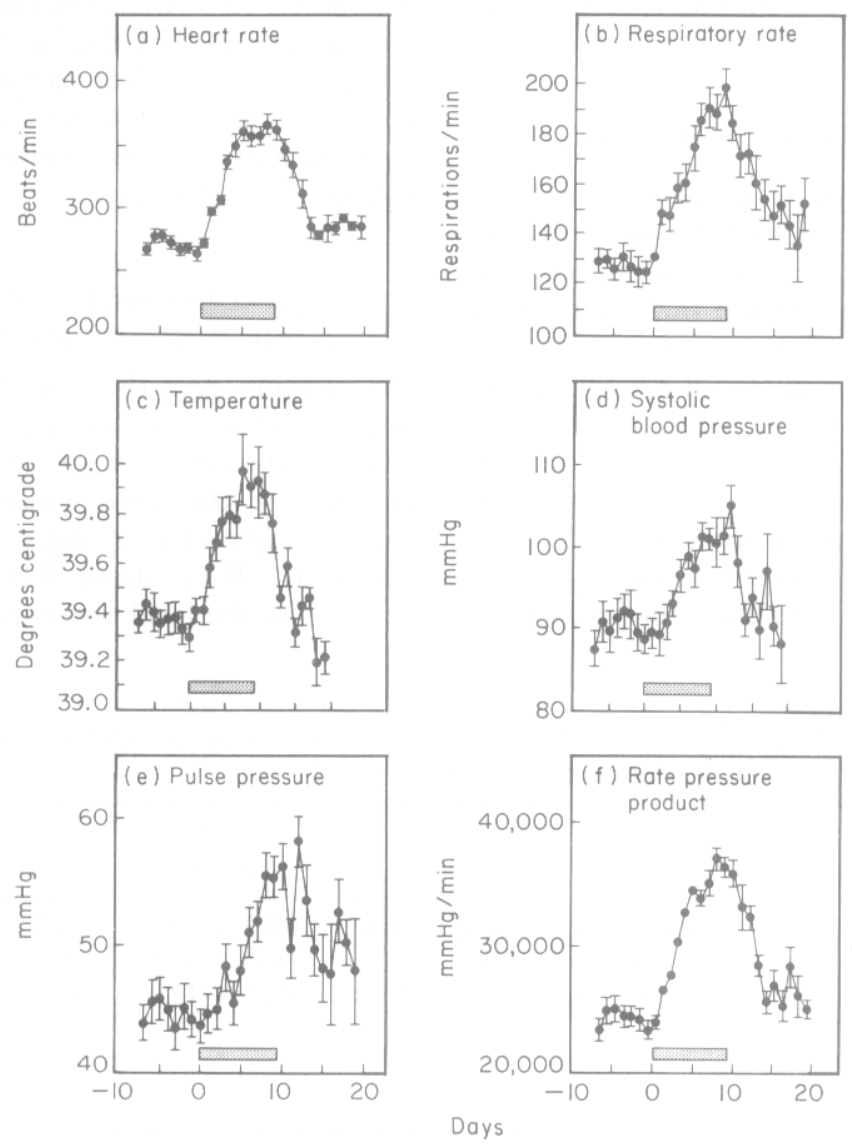

FIGURE 2. Changes in cardiac work during the development and regression of left ventricular cardiac hypertrophy were assessed by comparing various physiological parameters vs. time. Experimental animals were acclimated to housing and testing conditions for 1 week prior to receiving intravenous thyroxine $(200 \mu \mathrm{g} / \mathrm{kg} / \mathrm{d})$ for 9 days. Thyroxine was stopped, and regression was allowed to occur for up to 10 days. Values are mean \pm s.E.M. for $8-20$ observations at each time point. As is evident, heart rate (A), respiratory rate (B), temperature (C), systolic blood pressure (D), pulse pressure $(\mathbf{E})$, and rate-pressure product $(\mathbf{F})$ increased following administration of thyroxine. All parameters returned to control levels by the 3rd to 5 th day following cessation of hormone administration. 
animals $(310 \pm 39$ beats/min), but by the 5 th day following cessation of hormone the mean heart rate was similar to $\mathrm{C}-0$ values. Other physiological parameters (respiratory rate, body temperature, systolic blood pressure, pulse pressure, and rate-pressure product) responded similarly. Diastolic blood pressure was the only parameter studied which did not significantly change with thyroxine administration and withdrawal. These changes in physiolngical parameters directly or indirectly determine cardiac work (Morkin et al., 1983). Thus, the data in Figure 2 indicate that administration of thyroxine resulted in an increase in cardiac work that appeared to resolve within 3 to 5 days following cessation of the hormone.

\section{III. $\left[{ }^{3}\right.$ H]leucine infusion experiments}

$\left[{ }^{3} \mathrm{H}\right]$ leucine infusions were performed on a subset of 32 rabbits. Each of the four groups of animals used in the infusion experiments consisted of 8 randomly selected rabbits from the $\mathrm{C}-0, \mathrm{R}-0, \mathrm{R}-5$, and $\mathrm{R}-10$ groups. $F_{\max }^{*}$ and $K_{\mathrm{f}}$ were found to be similar in all groups (Table 2). However, plasma leucine flux (an index of whole-body protein synthesis) was significantly elevated in $\mathrm{R}-0$ animals and returned to the rate observed in $\mathrm{C}-0$ animals within 5 days after hormone withdrawal (Tablc 2). These changes in plasma leucine flux paralleled changes in the indices of cardiac work as described above (Fig. 2).

\section{Total and free thyroxine levels following administration and withdrawal of thyroxine}

Following administration of thyroxine for 9 days ( $\mathbf{R}-0$ animals), plasma concentrations of both total and free thyroxine were significantly elevated compared to $\mathrm{C}-0$ animals (Table 3). Cessation of thyroxine administration for 5 days resulted in a significant decrease in total thyroxine concentration below that of controls. By the 10th day, plasma total thyroxine concentration had returned to control values. In a similar fashion free thyroxine concentration fell by the 5 th day after discontinuing thyroxine but returned to control values by day 10 ; however, the transient decrease in free thyroxine concentration was not statistically significant.

\section{$V$. Effects of thyroxine administration and withdrawal on left ventricular tissue composition}

The cardiac growth seen during thyroxine administration was associated with an increase in the capacity for protein synthesis as assessed by the total tissue RNA concentration, expressed as $\mathrm{mg} / \mathrm{g} \mathrm{LV}$ wet weight (Table 4). Total tissuc RNA concentration returned to the level observed in $\mathrm{C}-0$ animals

TABLE 2. Plasma leucine specific radioactivity and leucine flux during regression of thyroxine-induced hypertrophy

\begin{tabular}{lcccc}
\hline & $\begin{array}{c}\mathrm{C}-0 \\
(n=8)\end{array}$ & $\begin{array}{c}\mathrm{R}-0 \\
(n=8\end{array}$ & $\begin{array}{c}\mathrm{R}-5 \\
(n=8)\end{array}$ & $\begin{array}{c}\mathrm{R}-10 \\
(n=8)\end{array}$ \\
\hline$F_{\max }^{*}(\mathrm{dpm} / \mathrm{nmol})$ & $1632 \pm 422$ & $1195 \pm 396$ & $1262 \pm 330$ & $1315 \pm 236$ \\
$K_{\mathrm{f}}$ (days) & $281 \pm 140$ & $257 \pm 40$ & $150 \pm 85$ & $315 \pm 229$ \\
Plasma & $35.9 \pm 8.8$ & $62.08 \pm 13.3^{*}$ & $45.0 \pm 11.1$ & $36.8 \pm 6.2$ \\
$\quad$ Leucine flux & & & & \\
$\quad(\mu \mathrm{mol} / \mathrm{h} / 100 \mathrm{~g})$ & & & &
\end{tabular}

Experimental animals were given intravenous thyroxine $(200 \mu \mathrm{g} / \mathrm{kg} / \mathrm{d})$ for 9 days. Thyroxine was stopped and regression allowed to occur for 0,5 , and 10 days $(R-0, R-5$, and $R-10$, respectively). Animals not receiving thyroxine served as controls $(\mathrm{C}-0) . F_{\max }^{*}$ and $K_{\mathrm{f}}$ are computer-derived values for the plasma leucine specific radioactivity at plateau, and the firstorder rate constant, respectively. Values are means \pm s.D. for each group; $n$, number of experimental animals in each group. $P$ values were obtained by ANOVA followed by StudentNewman-Keuls test comparing data from each group of experimental animals. Values are $P>0.05$ unless otherwise noted.

$* P<0.05$ vs. $\mathrm{C}-0$. 
TABLE 3. Plasma total thyroxine and free thyroxine during regression of thyroxineinduced-hypertrophy

\begin{tabular}{lcccc}
\hline & $\begin{array}{c}\mathrm{C}-0 \\
(n=8)\end{array}$ & $\begin{array}{c}\mathrm{R}-0 \\
(n=8)\end{array}$ & $\begin{array}{c}\mathrm{R}-5 \\
(n=8)\end{array}$ & $\begin{array}{c}\mathrm{R}-10 \\
(n=8)\end{array}$ \\
\hline $\begin{array}{l}\text { Total thyroxine } \\
(\mathrm{nmol} / \mathrm{l})\end{array}$ & $43.3 \pm 10.4$ & $90.4 \pm 41.3^{*} \dagger$ & $16.7 \pm 5.3^{*}$ & $38.3 \pm 9.2 \dagger$ \\
$\begin{array}{c}\text { Free thyroxine } \\
(\mathrm{pmol} / \mathrm{l})\end{array}$ & $15.3 \pm 4.6$ & $85.9 \pm 52.7^{*}$ & $2.5 \pm 1.4$ & $12.5 \pm 3.6$ \\
\hline
\end{tabular}

Experimental animals were given intravenous thyroxine $(200 \mu \mathrm{g} / \mathrm{kg})$ for 9 days. Thyroxine was stopped and regression allowed to occur for 0,5 , and 10 days $(R-0, R-5, R-10$, respectively $)$. Animals not receiving thyroxine served as controls $(\mathrm{C}-0)$. Values are means \pm s.D. for each group; $n$, number of experimental animals in each group. $P$ values were obtained by ANOVA followed by StudentNewman-Kuels test comparing data from each group of animals. Values are $P>0.05$ unless otherwise stated.

${ }^{*} P<0.05$ vs $\mathrm{C}-0$.

$\dagger P<0.05$ vs $\mathbf{R}-5$.

within 5 days following cessation of hormone administration. Total DNA concentration, expressed as $\mathrm{mg} / \mathrm{g} \mathrm{LV}$ wet weight, did not change significantly during administration or withdrawal of thyroxine. Only minor changes in LV TCP concentration ( $\mathrm{mg} / \mathrm{g} \mathrm{LV}$ wet weight) were observed during the treatment protocol. The total protein to DNA ratio did not change significantly following administration and withdrawal of thyroxine. In a similar fashion, thyroxine administration and withdrawal did not significantly alter the total RNA to DNA ratio.

\section{Rates of left ventricular protein accumulation and calculation of fractional growth rates during administration and withdrawal of thyroxine}

As in our previous studies of non-steady state cardiac protein turnover, weighted regression analysis afforded a means of quantifying rates of LV TGP accumulation or loss $\left(R_{\mathrm{g}}\right)$ during administration and withdrawal of thyroxine (Fig. 3). Weighted regression lines for LV TCP accumulation in control and thyrotoxic rabbits were obtained from our previous data (Parmacek et al., 1986; Samarel et al., 1987).

TABLE 4. Alterations in tissue composition during regression of thyroxine-induced hypertrophy

\begin{tabular}{lcccc}
\hline & $\begin{array}{c}\mathrm{C}-0 \\
(n=11)\end{array}$ & $\begin{array}{c}\mathrm{R}-0 \\
(n=11)\end{array}$ & $\begin{array}{c}\mathrm{R}-5 \\
(n=15)\end{array}$ & $\begin{array}{c}\mathrm{R}-10 \\
(n=16)\end{array}$ \\
\hline $\begin{array}{c}\text { Total RNA } \\
\text { (mg/g LV wet weight) }\end{array}$ & $1.75 \pm 0.22$ & $2.17 \pm 0.29^{*}$ & $1.76 \pm 0.19$ & $1.74 \pm 0.35$ \\
$\begin{array}{c}\text { Total DNA } \\
\text { (mg/g LV wet weight) }\end{array}$ & $1.73 \pm 0.38$ & $1.81 \pm 0.20$ & $1.52 \pm 0.40$ & $1.61 \pm 0.25$ \\
$\begin{array}{c}\text { Total protein } \\
\text { (mg/g LV wet weight) }\end{array}$ & $164 \pm 9$ & $172 \pm 10$ & $157 \pm 11 \dagger$ & $164 \pm 14$ \\
$\begin{array}{c}\text { Total protein/Total DNA } \\
\text { mg/mg) }\end{array}$ & $100 \pm 24$ & $96 \pm 9$ & $113 \pm 38$ & $104 \pm 20$ \\
$\begin{array}{c}\text { Total RNA/Total DNA } \\
\text { (mg/mg) }\end{array}$ & $1.05 \pm 0.18$ & $1.22 \pm 0.19$ & $1.29 \pm 0.62$ & $1.09 \pm 0.23$ \\
\hline
\end{tabular}

Nucleic acid and mixed cardiac protein concentration obtained from experimental animals given intravenous thyroxine ( $200 \mu \mathrm{g} / \mathrm{kg} /$ day) for 9 days. Thyroxine was stopped, and regression allowed to occur for 0,5 , and 10 days $(R-0, R-5)$, and $R-10$, respectively). Animals not receiving thyroxine served as controls $(\mathrm{C}-0)$. Values are mean \pm s.D.; $n$, number of experimental animals in each group. $P$ values obtained by ANOVA followed by Student-Newman-Kuels test comparing data for each experimental group. $P>0.05$ unless otherwise specified.

$* P<0.05$ vs. $\mathrm{C}-0$.

$+P<0.05$ vs. $\mathbf{R}-0$. 


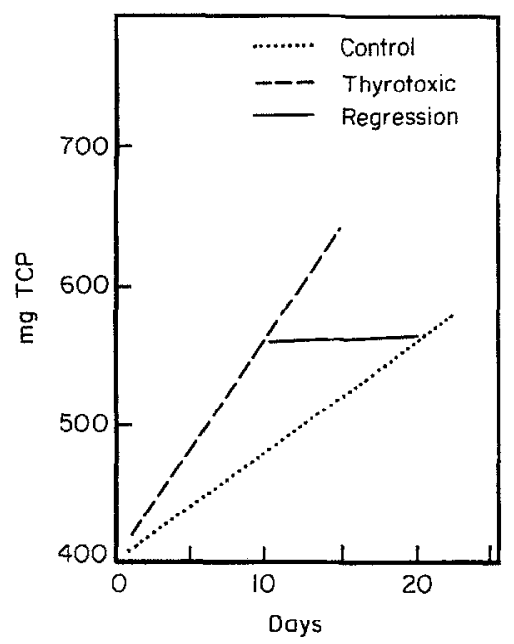

FIGURE 3. Comparison of left ventricular total cardiac protein (LV TCP) content vs. time. Data presented are weighted regression lines best describing LV TCP content vs. time for control (control), thyroxine treated (thyrotoxic), and regression (regression) animals. Control animals did not receive thyroxine and represent the TCP content of normally growing juvenile animals. Thyroxine treated animals received intravenous thyroxine $(200$ $\mu \mathrm{g} / \mathrm{kg} / \mathrm{d}$ ). Regression animals received intravenous thyroxine $(200 \mu \mathrm{g} / \mathrm{kg} / \mathrm{d})$ for 9 days and thyroxine was stopped. Following cessation of hormone administration, both normal and thyroxine-induced growth was suppressed such that LV TCP content eventually returned to control levels. Values for control and thyroxine treated animals were previously published by Parmacek et al. (1986) from this laboratory.

Of note, no differences could be demonstrated between the cardiac growth characteristics of animals used in previous experiments of thyroxine-induced left ventricular hypertrophy (Parmacek et al., 1986) and the control and thyroxine treated animals used in the present study. In a similar fashion, data for the 58 animals in the regression groups were plotted as mean LV TCP content (mg/ventricle) vs. days of regression. Sequential polynomial curve fitting and statistical analysis indicated that a straight line best fit the data for LV TCP content vs. time.

Thus, the TGP $R_{\mathrm{g}}$ for control and thyrotoxic rabbits were 8.1 and $15.9 \mathrm{mg} /$ day, respectively (Table 5). Five days following cessation of hormone administration, the TCP $\mathrm{R}_{\mathrm{g}}$ decreased to $0.6 \mathrm{mg}$ protein/day. Based on this analysis, TCP $R_{\mathrm{g}}$ was reduced to less than $10 \%$ of the value observed for normally growing control animals (i.e. $8.1 \mathrm{mg} /$ day). We conclude that this marked reduction in the TCP $R_{\mathrm{g}}$ is consistent with regression of $\mathrm{LV}$ hypertrophy despite a continued (albeit negligible) accumulation of protein following cessation of hormone administration. These values were subsequently used to calculate the instantaneous fractional rate of $\mathrm{LV}$ TCP accumulation $\left(K_{\mathrm{g}}\right)$ in the $\mathrm{C}-0, \mathrm{R}-0, \mathrm{R}-5$, and $\mathrm{R}-10$ animals used in protein synthesis experiments (Table 5). These calculations indicate that administration of thyroxine for 9 days resulted in a significant increase in TCP $K_{\mathrm{g}}$ when compared to controls. Upon discontinuation of thyroxine a marked suppression of TCP $K_{\mathrm{g}}$ values below both $\mathrm{C}-0$ and $\mathrm{R}-0$ levels were observed in the $R-5$ and $R-10$ animals.

\section{Alterations in LV protein synthesis and} degradation during administration and withdrawal of thyroxine

Data depicting alterations in LV TCP turnover during administration and withdrawal of thyroxine are also depicted in Table 5. Increased rates of both LV TCP $R_{\mathrm{s}}$ and TCP $R_{\mathrm{d}}$ were evident after 9 days of thyroxine administration. The accelerated accumulation of $\mathbf{L V}$ TCP in $\mathrm{R}-0$ animals was due to the greater increase in the rate of TCP $R_{\mathrm{s}}$ compared to TCP $R_{\mathrm{d}}$. Cessation of thyroxine administration resulted in a return of the TCP $R_{\mathrm{s}}$ to that observed in C-0 animals, whereas the TCP $R_{\mathrm{d}}$ remained elevated. Thus, return of the synthetic rate to $\mathrm{C}-0$ levels in conjunction with the persistently elevated degradative rate resulted in a negligible rate of TCP accumulation (i.e. a cessation of both hormone-induced and normal growth).

After 9 days of thyroxine administration, the efficiency of protein synthesis, expressed as mg TCP synthesized/day/mg RNA, was not significantly different 'from $\mathrm{C}-0$ animals (Table 5). Synthetic efficiency remained unchanged following cessation of hormone administration.

Data were also analyzed in terms of fractional rates of protein synthesis $\left(K_{\mathrm{s}}\right)$ and degradation $\left(K_{\mathrm{d}}\right)$. Following administration of thyroxine for 9 days the TCP $K_{\mathrm{s}}$ values were significantly elevated as compared to $\mathrm{C}-0$ animals. Discontinuation of thyroxine resulted in a return of TCP $K_{\mathrm{s}}$ values to that observed in $\mathrm{C}-0$ animals. In contrast, TCP $K_{d}$ was not 
TABLE 5. Left ventricular protein synthesis and degradation during regression of thyroxide-induced hypertrophy

\begin{tabular}{|c|c|c|c|c|}
\hline & $\begin{array}{c}\mathrm{C}-0 \\
(n=8)\end{array}$ & $\begin{array}{c}\mathrm{R}-0 \\
(n=8)\end{array}$ & $\begin{array}{c}\mathbf{R}-5 \\
(n=8)\end{array}$ & $\begin{array}{c}\mathrm{R}-10 \\
(n=8)\end{array}$ \\
\hline \multicolumn{5}{|c|}{ A. Protein Synthesized and Degraded per day: } \\
\hline $\begin{array}{l}\text { TCP synthetic rate } \\
\qquad\left(R_{\mathrm{s}}, \mathrm{mg} / \mathrm{d}\right)\end{array}$ & $37.9 \pm 8.9$ & $64.1 \pm 15.3^{*}$ & $44.3 \pm 5.5$ & $45.9 \pm 10.7$ \\
\hline $\begin{array}{l}\text { TCP accumulation rate } \\
\left(R_{g}, \mathrm{mg} / \mathrm{d}\right)\end{array}$ & +8.1 & +15.9 & +0.6 & +0.6 \\
\hline $\begin{array}{l}\text { TCP degradative rate } \\
\left(R_{\mathrm{d}}, \mathrm{mg} / \mathrm{d}\right)\end{array}$ & $29.8 \pm 8.9$ & $48.2 \pm 15.3^{*}$ & $43.7 \pm 5.5^{*}$ & $45.3 \pm 10.7^{*}$ \\
\hline $\begin{array}{l}\text { Efficiency of Protein Synthesis } \\
\text { (mg protein/day/mg RNA) }\end{array}$ & $8.3 \pm 1.9$ & $9.2 \pm 1.8$ & $8.2 \pm 1.4$ & $7.6 \pm 1.9$ \\
\hline \multicolumn{5}{|l|}{ B. Fractional Rates: } \\
\hline $\begin{array}{l}\text { TCP } K_{\mathrm{s}} \\
(\% / \text { day })\end{array}$ & $8.9 \pm 2.0$ & $11.5 \pm 2.0^{*}$ & $8.1 \pm 1.1$ & $8.2 \pm 1.8$ \\
\hline $\begin{array}{l}\operatorname{TCP} K_{\mathfrak{g}} \\
(\% / \text { day })\end{array}$ & $1.9 \pm 0.15$ & $2.9 \pm 0.37 *$ & $0.1 \pm 0.01 * \dagger$ & $0.1 \pm 0.01 * \uparrow$ \\
\hline $\begin{array}{l}\operatorname{TCP} K_{d} \\
(\% / \text { day })\end{array}$ & $7.0 \pm 2.0$ & $8.6 \pm 2.0$ & $8.0 \pm 1.1$ & $8.1 \pm 1.8$ \\
\hline
\end{tabular}

Experimental animals were given intravenous thyroxine $(200 \mu \mathrm{g} / \mathrm{kg} / \mathrm{d})$ for 9 days. Thyroxine was stopped and regression allowed to occur for 0,5 , and 10 days $(R-0, R-5$, and $R-10$, respectively). Animals not receiving thyroxine served as controls $(\mathrm{C}-0), R_{\mathrm{s}}, R_{\mathrm{g}}$ and $R_{\mathrm{d}}$ are the absolute rates of left ventricular protein synthesis, accumulation, and degradation, respectively. $K_{\mathrm{s}}, K_{\mathrm{g}}, K_{\mathrm{d}}$ are the fractional rates of left ventricular protein synthesis, accumulation, and degradation, respectively. Values are mean \pm s.D.; $n$, number of animals in each experimental group. $P$ values obtained by ANOVA followed by Student-Newman-Keuls test comparing data for each experimental group.

${ }^{*} P<0.05$ vs $\mathrm{C}-0$.

$+P<0.05$ vs $\mathrm{R}-0$.

significantly different after 9 days of thyroxine administration and remained at $\mathrm{C}-0$ levels following cessation of hormone administration. We interpret these results as indicating that removal of the stimulus for thyroxineinduced cardiac hypertrophy was not associated with an increased susceptibility of mixed cardiac proteins to proteolysis. Thus, regression of thyroxine-induced hypertrophy was not accompanied by a significant reduction in the average half-life of mixed cardiac proteins.

\section{Discussion}

The administration of thyroxine in the rabbit produces cardiac hypertrophy in vivo by increasing protein synthetic rates to a greater degree than degradative rates, resulting in the net accumulation of cardiac protein (Parmacek et al., 1986). As demonstrated in this report, the cessation of thyroxine administration results in regression of LV hypertrophy by returning rates of protein synthesis to control values while an increased amount of protein is degraded.

Following discontinuation of thyroxine administration, we observed a significant increase in terminal body weight as well as a return of hcart weight to body weight ratio towards control values. A similar rapid increase in body weight has been previously demonstrated in juvenile rats following cessation of thyroxine administration (Sanford $e^{t}$ al., 1978). However, this increase in body weight was not sufficient to return terminal body weight or the heart weight to body weight ratio to that expected for age matched, untreated controls. During the same period, we demonstrated that thyroxine administration produced a significant increase in the plasma concentrations of both total and free thyroxine. Following cessation of hormone administration, there was a dramatic, albeit transient, fall in total and free thyroxine concentrations which returned to control values by day 10. A similar suppression of thyroxine levels following cessation of hormone admini- 
stration has been previously demonstrated in humans receiving exogenous thyroid hormone (Vagenakis et al., 1975). Thus, despite the low concentrations of free and total thyroxine following the cessation of hormone administration, there was an accelerated increase in body weight, suggesting that this weight gain occurred independent of plasma thyroxine concentrations.

The methods employed to estimate fractional rates of protein synthesis and degradation are based on the assumption that during constant intravenous infusion of $\left[{ }^{3} \mathrm{H}\right]$ leucine there is rapid and complete equilibration between leucyl-tRNA and plasma leucine. We have previously demonstrated in both untreated rabbits and rabbits treated with thyroxine for 3 days that plasma leucine specific radioactivity and cardiac leucyl-tRNA specific radioactivity are nearly identical following a constant infusion of $\left[{ }^{3} \mathrm{H}\right]$ leucine (Parmacek et al., 1986). Thus, plasma leucine specific radioactivity accurately reflects the cardiac leucyl-tRNA pool and is acceptable for use in the calculation of fractional protein synthetic rates for both thyroxine-treated and untreated control animals. However, it is possible that during regression of thyroxine-induced cardiac hypertrophy this relationship is altered, leading to a systematic underestimation of total protein fractional synthetic rates.

Our results support the findings of previous investigators regarding the effect of thyroxine administration on protein synthesis during the development of cardiac hypertrophy (Bonnin et al., 1983; Carter et al., 1982; Parmacek et al., 1986; Crie et al., 1983). We demonstrated a $70 \%$ increase in the TCP $R_{\mathrm{s}}$ and a $62 \%$ increase in the TCP $R_{\mathrm{d}}$ following thyroxine administration; values similar to those previously reported by this laboratory (Parmacek $e t$ al., 1986). Our present data also indicate that, in addition to increasing rates of protein turnover, thyroxine administration resulted in hemodynamic alterations that increased cardiac work. The temporal relationship between increased cardiac work, augmented rates of protein synthesis, and the development of cardiac hypertrophy strongly supports recent observations regarding the relative importance of thyroxine mediated changes in cardiac work vs. the direct effects of thyroxine on nyocardial protein metabolism (Klein, 1988;
Klein et al., 1986; Koreckey et al., 1987). Thus, our results suggest that thyroxine-mediated alterations in cardiac work play a significant role in modulating rates of protein synthesis required for the development of cardiac hypertrophy.

Following cessation of thyroxine administration, we demonstrated: (a) reduced TCP synthetic rates $\left(R_{\mathrm{s}}\right)$; (b) the return of indices of cardiac work to control levels, and (c) the cessation of both normal and hormoneinduced growth. We defined regression as a return of LV TCP mass towards that of agematched controls. Since juvenile animals were used throughout the study period, cardiac mass was continually increasing in the control population due to physiologic growth. Thus, regression may have resulted from one of two mechanisms: (a) an absolute decrease in LV ICP mass or (b) a decreased TCP $R_{\mathrm{g}}$ compared to normally growing control animals. Our data support the latter mechanism and show that LV TCP mass did not change upon cessation of hormone administration, but eventually reached a value equal to that of the control group. Thus, regression of thyroxineinduced cardiac hypertrophy was mediated, in part, by a return of the increased TGP $R_{\mathrm{s}}$ back to normal. These results in the rabbit differ somewhat from observations of thyroxine-induced cardiac hypertrophy in rats. Previous investigators using rats have shown an absolute decrease in both heart weight (Sanford et al., 1978; Campbell and Gerdes, 1988) and cardiomyocyte volume (Campbell and Gerdes, 1988) following cessation of thyroxine administration. These observations may reflect age, sex, and/or species differences between the experimental models.

Changes in protein synthetic rates can result from either altered protein synthetic efficiency and/or capacity (Morgan et al., 1987). We previously demonstrated that $\mathrm{LV}$ protein synthetic efficiency was augmented after 3 days of thyroxine administration, but returned to control levels by day 9 of hormone treatment. Conversely, the capacity for protein synthesis was unchanged after 3 days of hormone administration, but was significantly increased by the second week of thyroxine treatment (Parmacek et al., 1986). Similar alterations in cardiac protein synthetic efficiency and capacity in vivo have been demon- 
strated during the development of right ventricular hypertrophy due to pulmonary artery banding (Nagai et al., 1988). In contrast, Siehl et al., (1985) demonstrated no change in protein synthetic efficiency in their in vitro studies of thyroxine-induced rat cardiac hypertrophy. They reported a more modest increase in protein synthesis $25 \%$ above control in their study) following daily administration of thyroxine for 4 days. However, protein synthetic rates were measured in both the control and thyroxine treated animals using an isolated, perfused working heart preparation under identical conditions of temperature, coronary flow, aortic perfusion pressure, and substrate supply. Thus, the thyroxine-induced alterations in body temperature and ventricular loading (which we have demonstrated to occur in vivo in response to thyroxine) were not simulated. Therefore, their contribution to accelerated protein synthesis and protein synthetic efficiency were not assessed in the study by Siehl et al. (1985).

In contrast to changes demonstrated during the development of thyroxine-induced hypertrophy, regression was not associated with alterations in protein synthetic efficiency, although a reduction in capacity (as evidenced by a return of total RNA concentration to control values) was observed. Nevertheless, removal of the stimulus for hormone-induced growth affected both total protein and RNA turnover. Whether the reduction in RNA concentration and content that accompanied regression was the result of decreased synthesis, or increased degradation of myocyte ribosomal RNA requires additional investigation.

We did not demonstrate a change in the total DNA concentration or total protein to DNA ratio during the development or regression of thyroxine-induced left ventricular hypertrophy. These data indicate that, in the absence of polyploidy, some degree of hyperplasia occurred. Similar results were noted by Parmacek et al. (1986) who found no change in the total DNA concentration following 9 days of thyroxine administration. While cardiac myocytes lose their mitotic capacity shortly after birth, the interstitial and vascular cell populations retain their ability to divide. The tissue homogenates used to measure total protein and nucleic acid content sampled all the varicus cardiac cell populations. Thes, the failure to demonstrate a change in total DNA concentration or total proteir to DNA ratio probably reflects the inyperplastic response of the non-myocyte cell populations to thyroxine-induced growth.

The results from this report indicate that protein degradation played a relatively passive role in the regulation of cardiac protein mass following administration and withdrawal of thyroxine. The intracellular mechanisms responsible for accelerated protein degradation during the development and regression of cardiac hypertrophy are unknown. It is generally assumed that the kinetics of protein degradation can best be described as a first-order process, in which the rate of protein degradation $\left(R_{\mathrm{d}}\right)$ is dependent upon the amount of protein present, and the magnitude of a first-order rate constant, i.e. the fractional rate of degradation $\left(K_{d}\right)$ characterizing the susceptibility of proteins to cegradation (Waterlow et al., 1978). In our previous report (Parmacek ei al., 1986), we showed that TCP $K_{\mathrm{d}}$ was transiently elevated during the development of thyroxine-induced cardiac hypertrophy, but by the 9 th day of hormone administration TCP $K_{\mathrm{d}}$ values were similar to that observed in control rabbits. In the present study, we demonstrated that TCP $K_{\mathrm{d}}$ values remain unchanged following hormone withdrawal. These results suggest that regression of thyroxine-induced bypertrophy was not associated with an increased susceptibility of mixed cardiac proteins to proteolysis. Thus, the $R_{\mathrm{d}}$ remained elevated during the regression period, not because of an increased fraction of susceptible proteins, but because of an expanded total protein pool size. It must be recognized, however, that these $K_{\mathrm{d}}$ values are representative of and describe the kinetic behavior of a mixture of all cardiac proteins. It is conceivable that the susceptibility to proteolysis of individual proteins (including myofibrillar proteins) may differ during regression. Further studies are needed to evaluate the susceptibility of individual myofibrillar proteins to proteolysis (i.e. $K_{\mathrm{d}}$ values) during both the development and regression of thyroxine-induced cardiac hypertrophy.

Finally, although this report provides cvidencc to indicate that accelerated rates of protein degradation are at least partly respon- 
sible for the regression of cardiac protein mass following cessation of thyroxine, the subcellular sites and mechanisms responsible for the regulation of contractile protein turnover are unknown. Based upon this kinetic analysis it "ppears that regression from hypertrophy in juvenile animals is largely the result of changes in protein synthetic rates. The accelerated rates of protein degradation noted during the regression phase reflect the increased mass of the hypertrophied ventricle.

\section{Acknowledgements}

The authors thank Ms Melanie Alm and $\mathrm{Mr}$ Alan Ferguson for their expert technical assistance in performing these experiments. They also thank Ms Carolyn Moffett for her assistance in the preparation of this manuscript. These studies were supported by $\mathrm{Na}$ tional Heart, Lung, and Blood Institute grants HL-34328 and HL-19648. Dr Samarel is the recipient of a National Heart, Lung, and Blond Institute Research Career Development Award.

\section{References}

Beznak M, Korecky B, Thomas G (1969) Regression of cardiac hypertrophies of various origin. Can J Physiol Pharmacol 47: 579-586.

Bonnin CM, Sparrow MP, TAylor RT (1983) Increased protein synthesis and degradation in the dog heart during thyroxine administration. J Mol Cell Cardiol 15: 245-250.

Campbell SE, Gerdes AM (1988) Regional changes in myocyte size during the reversal of thyroid-induced cardiac hypertrophy. J Mol Cell Cardiol 20: 379-387.

Carter WJ, Benjamin WS, FAss FH (1982) Effect of experimental hyperthyroidism on protein turnover in skeletal and cardiac muscle measured by $\left[{ }^{14} \mathrm{C}\right]$ tyrosine infusion. Biochem $\mathrm{J}$ 204: 69-74.

CESARONe CF, Bolognesi G, SANTI L (1979) Improved microfluormetric DNA determination in biological materials using 33258 Hoechst. Anal Biochem 100: 118-197.

Crie JS, WAkeland JR, Mayhew BA, Wildenthal. K (1983) Direct anabolic effects of thyroid hormone on isolated mouse heart. Am J Physiol 245: C.328-C.333.

Everett AW, Sinha AM, Umeda PK, Jakovaic S, Rabinowitz M, ZaK R (1984) Regulation of mysin synthesis by thyroid hormone: relative change in the $\alpha$ - and $\beta$-myosin heavy chain in RNA levels in rabbit heart. Biochemistry 23 : 1596-1599.

Everett AW, Sparrow MP, IAylor RR (1979) Early changes in myocardial protein synthesis in vivo in response to right ventricular pressure overload in the dog. J Mol Cell Cardiol 11: 1253-1263.

Garlick PJ, Millward DJ, James WPT, Waterlow JC (1975) The effect of protein deprivation and starvation on the rate of protein syntehsis in tissues of the rat. Biochim Biophys Acta 414: 71-84.

Gustafson TA, Markham BE, Morkin E (1986) Effects of thyroid hormone on $\alpha$-actin and myosin heavy chain gene expression in cardiac and skeletal muscles of the rat: measurement of mRNA content using synthetic oligeonucleotide probes. Circ Res 59: 194-201.

KLEIN I (1988) Thyroxine-induce cardiac hypertrophy: time course of development and inhibition by propranolol. Endocrinology 123: 203-210.

Klein I, Hong G (1986) Effects of thyroid hormone on cardiac size and myosin content of the heterotopically Lransplanted rat heart. J Clin Invest 77: 1694-1698.

Korecky B, Zak R, Schwartz K, Aschenbrenner V (1987) Role of thyroid hormone in regulation of isomyosin composition, contractility, and size of heterotopically isotransplanted rat heart. Circ Res 60, 824-830.

Lowry OH, Rosebrough NJ, Fan LA, Randall RJ (1951) Protein estimation with the Folin-phenol reagent. J Biol Chem 193: 265-275.

Milimard DS, Garlick PJ, James PT, Nmanyelugo, Ryatt JS (1973) Relationship between protein synthesis and RNA content in skeletal muscle. Nature [Lond] 241: 204-205.

Morgan He, Gordan Ee, Kira Y, Chua BHL, Russo la, Peterson CJ, MaDermott PJ, Watson PA (1987) Biochemical mechanisms of cardiac hypertrophy. Ann Rev Physiol 49: 533-543.

Morkin E, Flink IL, Goldman S (1983) Biochemical and physiologic effects of thyroid hormone on cardiac performance. Prog Cardiovasc Dis 25: $435-464$.

MunRo HN, Fleak A (1966) The determination of nucleic acids. In: Methods of Biochemical Analysis, edited by D Glick. New York, Interscience vol 14: 113-176.

Nagai R, Low RB, Stirewalt WE, Alpert NR, LitTen RZ (1988) Efficiency and capacity of protein synthesis are increased in pressure overload cardiac hypertrophy. Am J Physiol 255: II325-H320.

Pandis IP, Kotler MN, Ren JF, Montz GS, Ross J, Kalman P (1984) Development and regression of left ventricular hypertrophy. J Am Coll Cardiol 3: 1309-1320.

Parmacex MS, Magid MN, Lesch M, Degker RS, Samarel AM (1986) Cardiac protein synthesis and degradation during thyroxine-induced left ventricular hypertrophy. Am J Physiol 251: C727-C736.

Samarel AM, Parmacex MS, Magid NM, Degker RS, Lesch M (1987) Protein synthesis and degradation during starvation-induced cardiac atrophy in rabbits. Circ Res 60: 933-941. 
Samarel AM, Ogunro EA, Ferguson AG, Allenby P, Lesch M (1981) Rabbit cardiac immunoreactive cathepsin D content during starvation-induced atrophy. Am J Physiol 240: H222-H228.

SANFord CF, GRIFFin EE, Wildential K (1978) Synthesis and degradation of myocardial protcin during the development and regression of thyroxine-induced cardiac hypertrophy in rats. Circ Res 43: 688-694.

Siehl D, Chua BHL, Lautensagk-Beiser N, Morgan HE (1985) Faster protein and ribosome synthesis in thyroxineinduced hypertrophy of rat heart. Am J Physiol 248: C309-C319.

Vagenakis AG, Braverman LE, Azizi F, Portnay GI, Ingbar SH (1975) Recovery of pituitary thyrotropic function after withdrawal of prolonged thyroid-suppression therapy. N Engl J Med 293: 681-684.

Waterlow JC, Garlick PJ, MrLward DJ (1978) Basic concepts. In: Protein Turnover in Mammalian Tissues in the Whole Body, edited by Waterlow JC, Garlick PJ, Milward DJ. Amsterdam, Elsevier North Holland Biomedical Press, PP $179-249$

WATERLOW JC, STEPHEN JML (1967) The measurement of total lysine turnover in the rat by intravenous infusion of L-[U-14 G]lysine. Clin Sci 33: 489-506.

Wilson DM, Romero JC, Strong CG, Lee KE, Schryver SM (1975) Indirect blood pressure measurements in the rabbit: correlations with direct aortic and ear pressures. J Lab Clin Med 86: 1032-1039.

Zak R, Ghizzonite RA, Everett AW, Clark WA (1982) Study of ventricular isomyosins during normal and thyroid hormone induced cardiac growth. J Mol Gell Gardiol 14, [Suppl. 3]: 111-117. 